2013-03-06

Benthic foraminifera show some resilience to ocean acidification in the northern Gulf of California, Mexico.

Pettit, LR

http://hdl.handle.net/10026.1/1451

10.1016/j.marpolbul.2013.02.011

Mar Pollut Bull

Elsevier BV

All content in PEARL is protected by copyright law. Author manuscripts are made available in accordance with publisher policies. Please cite only the published version using the details provided on the item record or document. In the absence of an open licence (e.g. Creative Commons), permissions for further reuse of content should be sought from the publisher or author. 


\title{
Benthic foraminifera show some resilience to ocean acidification in the northern Gulf of California, Mexico
}

\author{
L.R. Pettit ${ }^{\text {a,* }}$, M.B. Hart ${ }^{\mathrm{a}}$, A.N. Medina-Sánchez ${ }^{\mathrm{b}}$, C.W. Smart ${ }^{\text {, }}$, R. Rodolfo-Metalpa ${ }^{\mathrm{a}}$, J.M. Hall-Spencer ${ }^{\mathrm{a}}$, \\ R.M. Prol-Ledesma ${ }^{\mathrm{c}}$ \\ a Marine Institute Plymouth University, Drake Circus, Plymouth PL4 8AA, United Kingdom \\ ${ }^{\mathrm{b}}$ Posgrado en Ciencias del Mar y Limnología, Universidad Nacional Autónoma de México, Ciudad Universitaria, Delegación Coyoacán, 04510 México D.F., Mexico \\ ' Instituto de Geofísica, Universidad Nacional Autónoma de México, Ciudad Universitaria, Delegación Coyoacán, 04510 México D.F., Mexico
}

\section{A R T I C L E I N F O}

Keywords:

Benthic foraminifera

Vent systems

Gulf of California

Ocean acidification

\begin{abstract}
A B S T R A C T
Extensive $\mathrm{CO}_{2}$ vents have been discovered in the Wagner Basin, northern Gulf of California, where they create large areas with lowered seawater $\mathrm{pH}$. Such areas are suitable for investigations of long-term biological effects of ocean acidification and effects of $\mathrm{CO}_{2}$ leakage from subsea carbon capture storage. Here, we show responses of benthic foraminifera to seawater $\mathrm{pH}$ gradients at $74-207 \mathrm{~m}$ water depth. Living (rose Bengal stained) benthic foraminifera included Nonionella basispinata, Epistominella bradyana and Bulimina marginata. Studies on foraminifera at $\mathrm{CO}_{2}$ vents in the Mediterranean and off Papua New Guinea have shown dramatic long-term effects of acidified seawater. We found living calcareous benthic foraminifera in low $\mathrm{pH}$ conditions in the northern Gulf of California, although there was an impoverished species assemblage and evidence of post-mortem test dissolution.
\end{abstract}

(C) 2013 Elsevier Ltd. All rights reserved.

\section{Introduction}

Over the past 200 years, the oceans have absorbed almost a third of the carbon dioxide produced by the burning of fossil fuels (Sabine et al., 2004). This has resulted in a series of chemical changes, including lowering the $\mathrm{pH}$, in a process known as ocean acidification (Caldeira and Wickett, 2003). In this context, 'acidified' refers to the process of becoming closer to chemical acidity, not that the seawater is chemically acidic (i.e. below $\mathrm{pH}$ 7.0). Since pre-industrial times, the ocean surface $\mathrm{pH}$ has fallen by approximately 0.1 units to a current day global average of 8.1 , which is equivalent to a $30 \%$ increase in the concentration of hydrogen ions (Guinotte and Fabry, 2008). The current rate and magnitude of $\mathrm{pH}$ changes is thought to be greater than any inferred from the past 300 million years and the ocean surface pH may fall by as much as 0.77 units (Caldeira and Wickett, 2003). These chemical changes are expected to have significant consequences for marine organisms, particularly those with calcareous shells (Kroeker et al., 2010; Rodolfo-Metalpa et al., 2011). Benthic foraminifera are an important group to examine as they occur worldwide, have short life-histories, are environmentally sensitive and have an excellent fossil record (Dias et al., 2010). Much of the work conducted on foraminifera in relation to ocean acidification has involved shortterm laboratory experiments (Bijma et al., 2002, 1999; Spero

\footnotetext{
* Corresponding author.

E-mail address: laura.pettit@plymouth.ac.uk (L.R. Pettit).
}

et al., 1997), deep sea $\mathrm{CO}_{2}$ storage scenarios with very high levels of $\mathrm{CO}_{2}$ (Bernhard et al., 2009a,b) or micropalaeontological investigations (Barker and Elderfield, 2002; Gonzalez-Mora et al., 2008; Moy et al., 2009; Nguyen et al., 2009).

Natural $\mathrm{CO}_{2}$ vents can be used to study the effects of ocean acidification in situ, as they create areas of lower $\mathrm{pH}$ where carbon dioxide gas bubbles up through the sea floor (Dias et al., 2010). Some of these vents release gas (and water) at ambient seawater temperatures. The vents tend to be present on time scales of hundreds to thousands of years, so the communities present in the area are likely to be adapted to the low $\mathrm{pH}$ conditions, avoiding some of the problems of short-term, rapid perturbation experiments (Hall-Spencer et al., 2008). These $\mathrm{CO}_{2}$ vents can also be used to examine the potential biological impacts of leakage from carbon capture storage (CCS) sites. There is concern that leakage from CCS will impact biological communities, as a result of perturbations in the carbonate chemistry conditions and a reduction in $\mathrm{pH}$ (Blackford et al., 2009). Bernhard et al. (2009a) conducted an experiment to examine the survival of deep-sea benthic foraminifera under a potential carbon dioxide sequestration scenario. They found that the survivorship of allogromiid and agglutinated foraminifera was not significantly affected, but calcareous foraminifera had a significantly lower survivorship in exposure treatments compared to controls.

Examination of benthic foraminiferal assemblages in relation to ocean acidification from natural situations is both important and lacking in the literature. Dias et al. (2010) examined living 
assemblages of benthic foraminifera around natural $\mathrm{CO}_{2}$ vents adjacent to the island of Ischia, Italy. They found that the community changed from one dominated by calcareous forms in normal $\mathrm{pH}$ conditions to one dominated by agglutinated forms in lowered $\mathrm{pH}$ conditions. Along a gradient from normal $\mathrm{pH}$ (mean $\mathrm{pH} \sim 8.14$ ) to acidified areas (mean $\mathrm{pH} \sim 7.6$ ), species richness fell from 24 to just four species of benthic foraminifera. The reduction in species richness near to the $\mathrm{CO}_{2}$ vents mirrored those found for larger benthic calcifying organisms (Hall-Spencer et al., 2008). In addition, Fabricius et al. (2011), who examined calcareous biota at $\mathrm{CO}_{2}$ vents off Papua New Guinea, found that sediment at high $p \mathrm{CO}_{2}$ sites (up to $953 \mathrm{ppm}$ ) was almost free of calcareous biota (including benthic foraminifera) and sites with lower $p \mathrm{CO}_{2}(\sim 444 \mathrm{ppm})$ contained many pitted or eroded tests of foraminifera. A taxonomic assessment of the assemblage was, however, not undertaken as part of the investigation at Papua New Guinea. In another study at $\mathrm{CO}_{2}$ vents around Papua New Guinea, Uthicke and Fabricius (2010) examined the symbiont-bearing benthic foraminifera, Marginopora vertebralis (Quoy and Gaimard). They found M. vertebralis to be absent from three seep sites with $\mathrm{pH}$ below $\sim 7.9$, but present in densities of over $1000 \mathrm{~m}^{-2}$ at control sites.

The Gulf of California is a narrow marginal sea. In the northern part, upwelling creates high, but variable nutrient levels (Halfar et al., 2004). Rates of primary productivity are similar to those in the Bay of Bengal or North Africa and they are approximately 2-3 times greater than the open Atlantic at similar latitudes (Zeitzschel, 1969). The region has a high evaporation rate with strong winds and tides. Fast tidal currents that develop, particularly in spring, create a well-mixed water column which persists for most of the year (Zeitzschel, 1969). This strong mixing means that temperatures at depth in the basin are almost constant. The Wagner and Consag basins have large areas in which the $\mathrm{pH}$ is naturally lower due to gas seepage across the basins. In 2007 and 2010, gas vents along the Wagner Fault, in the northern Gulf of California were examined. Over 300 large, diffuse seafloor gas vents were discovered (Canet et al., 2010) causing dramatic changes to the carbonate chemistry. The vent gases are probably methane and $\mathrm{CO}_{2}$ rich (Canet et al., 2010), although $\mathrm{CO}_{2}$ predominates in the whole area (Prol-Ledesma et al., 2013). The Wagner and Consag basins are shallow (up to $\sim 225 \mathrm{~m}$ ) active basins in the north of the Gulf of California with large-scale gas venting, along the eastern edge of the basins (Canet et al., 2010).

The aims of our study were to examine; (1) the response of living benthic foraminifera and, (2) the preservation of living and dead benthic foraminifera, in different seawater $\mathrm{pH}$ conditions in the northern Gulf of California. Our hypothesis was that there would be an overall reduction in species richness and a reduction in calcifying species in the areas with lower $\mathrm{pH}$ conditions. We also expected that there would be test dissolution in the lowest $\mathrm{pH}$ conditions as this has been shown in other foraminiferal studies (Le Cadre et al., 2003; Moy et al., 2009).

\section{Materials and methods}

Samples were collected during the WAG-02 cruise aboard R/V El Puma. Sample stations were chosen to represent the variations in $\mathrm{pH}$ due to the presence of vents (Fig. 1). Sediment samples were collected using a Smith McIntyre grab. Once aboard the research vessel, $10 \mathrm{~cm}$ cores were taken through the sediment, which were then divided into $2 \mathrm{~cm}$ sub-samples. The sediment was stained with rose Bengal $(1 \mathrm{~g} / \mathrm{L})$ and preserved in $4 \%$ formalin for up to 3 months, until the samples were processed.

Rosette mounted CTD casts (General Oceanics, Mark III WOOCE) were taken at every sampling station to monitor environmental parameters. Seawater samples were collected $10 \mathrm{~m}$ above the bot- tom to avoid physical damage to the CTD. To test if seawater samples collected a few centimetres above the seabed differed significantly from ones collected $10 \mathrm{~m}$ above the bottom, near-bottom water samples were taken at two sampling stations. A Niskin bottle was connected to an ROV arm with a hand-made system. Seawater bottom samples collected using the ROV did not differ significantly from seawater collected $10 \mathrm{~m}$ above the seabed using the rosette.

On-board, seawater sub-samples were immediately collected from the recovered rosette in glass bottles. The $\mathrm{pH}_{\mathrm{T}}$ (in total scale) was measured using a meter (Methrom $\mathrm{pH}$ mobile) accurate to $0.01 \mathrm{pH}$ units and calibrated using TRIS/HCl and 2-aminopyridine/HCl buffer solutions (Dickson et al., 2007). Seawater samples were then passed through Whatman GF/F, treated with $0.05 \mathrm{ml}$ of $50 \% \mathrm{HgCl}_{2}$ (Merck, Analar) and stored in the dark at $4{ }^{\circ} \mathrm{C}$ pending analysis. Three replicate $20 \mathrm{ml}$ sub-samples were analysed at $25^{\circ} \mathrm{C}$ using a titration system composed of a pH-meter with a Methrom pH electrode and a $1 \mathrm{ml}$ automatic burette (METHROM). $\mathrm{pH}$ was measured at $0.02 \mathrm{ml}$ increments of $0.1 \mathrm{~N} \mathrm{HCl}$. Total alkalinity $\left(A_{\mathrm{T}}\right)$ was calculated from the Gran function applied to $\mathrm{pH}$ from 4.2 to 3.0 , as $\mathrm{mEq}^{-1}$ from the slope of the curve; $\mathrm{pH} v s . \mathrm{HCl}$ volume. Titrations of total alkalinity standards, provided by A.G. Dickson Laboratory (batch 99 and 102; Scripps Institution of Oceanography), were within $0.7 \mu \mathrm{mol} \mathrm{kg}{ }^{-1}$ of the nominal value. Parameters of the carbonate system $\left(p \mathrm{CO}_{2}, \mathrm{CO}_{3}^{2-}, \mathrm{HCO}_{3}^{-}, \mathrm{C}_{\mathrm{T}}\right.$ and saturation state of calcite $\left(\Omega_{\text {Calc }}\right)$ and aragonite $\left(\Omega_{\text {Arag }}\right)$ ) were calculated from $\mathrm{pH}_{\mathrm{T}}$, mean $A_{\mathrm{T}}$, temperature and salinity using the free-access CO2SYS package (Lewis and Wallace, 1998) with the constants of (Mehrbach et al., 1973). pH is expressed on the total scale at the sampled depth of collection. $A_{\mathrm{T}}$ was virtually constant at all sites, therefore its mean was used in the calculation of the carbonate chemistry parameters $\left(A_{\mathrm{T}}=2359.01 \mu \mathrm{mol} \mathrm{kg}{ }^{-1}\right)$. Means of $\mathrm{pH}_{\mathrm{T}}$ were calculated from hydrogen ion concentrations of each measurement and then re-converted back to pH (Dickson et al., 2007).

Only the core top $(0-2 \mathrm{~cm})$ samples were analysed as this is the segment most suitable for finding live foraminifera (Corliss, 1985). Standard micropalaeontological techniques were employed with samples washed on a $63 \mu \mathrm{m}$ sieve (Murray, 2006). The retained fraction was left to air dry for up to $72 \mathrm{~h}$. Once dry, the sediment was transferred to labelled plastic weighing vials. Prior to analysis, sediment samples were split using an Otto sediment splitter. Split samples were placed onto a brass picking tray and analysed under the stereo-binocular microscope. Individual foraminifera were dry picked using a fine paint brush and placed onto micropalaeontological slides. The foraminifera were identified, in the first instance, using (Loeblich and Tappan, 1987, 1964) and identified to species level, where possible, using Bandy (1961, 1953), Brenner (1962), McGann (2002) and Lesen (2005). The smallest split fraction was examined first. If at least 300 individuals were found within the fraction, no additional fractions were examined from this sample as 300 individuals are believed to be statistically representative of the whole sample (Pielou, 1966). If fewer than 300 individuals were found then an additional fraction was examined. This continued until at least 300 individuals had been found, or the whole sample had been examined, whichever came first. The rose Bengal stain was used to determine living individuals. Individuals were determined to have been live at the time of collection if they were stained dark magenta in at least half of their chambers. This excluded counting individuals with just a faint red dot in one chamber. As rose Bengal is a non-vital stain, it also has the potential to stain remaining protoplasm or bacteria, thereby overestimating the number of living individuals (Bernhard et al., 2006). It can also be difficult to see the staining in opaque specimens including many species of agglutinated foraminifera (Bernhard, 2000). If used carefully, however, rose Bengal can be reasonably accurate in certain 


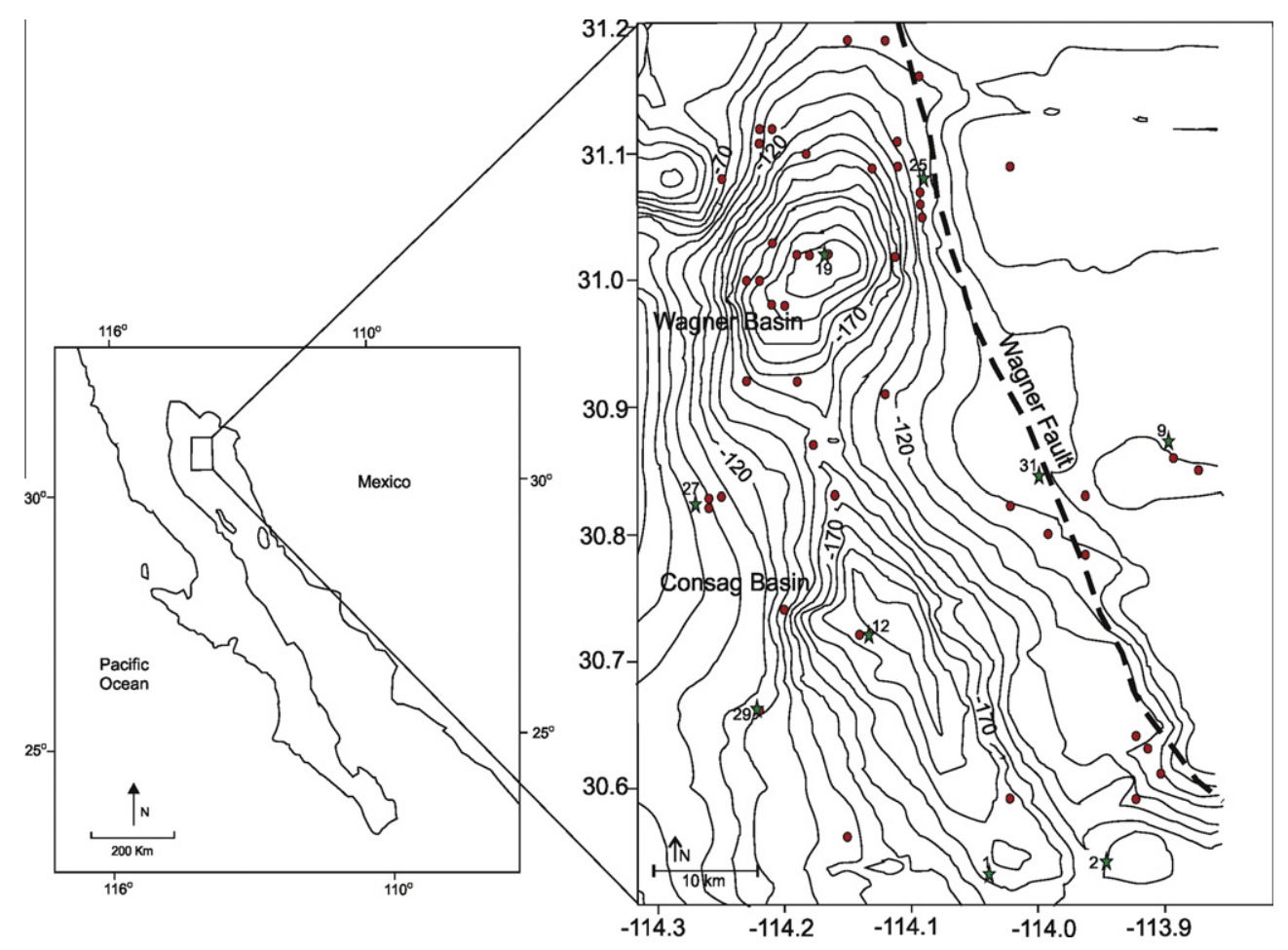

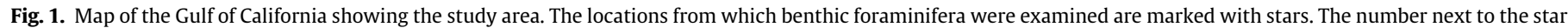
refers to the station number. Circles represent the position of $\mathrm{CO}_{2}$ vents in the area.

Table 1

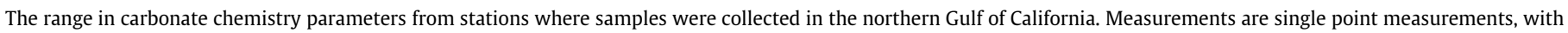
no replicates. Measurements were taken in July and August 2010.

\begin{tabular}{|c|c|c|c|c|c|c|c|c|c|}
\hline Station & Depth (m) & Temp $\left({ }^{\circ} \mathrm{C}\right)$ & Salinity (\%o) & $\mathrm{pH}_{\mathrm{T}}$ & $\Omega_{\text {Calc }}$ & $p \mathrm{CO}_{2}(\mu \mathrm{atm})$ & $A_{\mathrm{T}}\left(\mu \mathrm{mol} \mathrm{kg}{ }^{-1}\right)$ & Living calcareous foraminifera & Dead calcareous foraminifera \\
\hline 31 & 80 & 20.6 & 35.4 & 7.88 & 3.60 & 674 & 2330.55 & $\mathrm{X}$ & $\nu$ \\
\hline 27 & 88 & 20.4 & 35.4 & 7.86 & 3.46 & 675 & - & $\mathrm{X}$ & $\nu$ \\
\hline 25 & 80 & 23.3 & 35.5 & 7.83 & 3.61 & 730 & 2386.43 & レ & $\boldsymbol{\nu}$ \\
\hline 9 & 74 & 22.4 & 35.5 & 7.83 & 3.50 & 735 & 2363.00 & レ & $\boldsymbol{\nu}$ \\
\hline 29 & 105 & 20.0 & 35.4 & 7.75 & 2.69 & 917 & 2382.21 & $\boldsymbol{\nu}$ & レ \\
\hline 12 & 195 & 14.0 & 35.2 & 7.69 & 1.90 & 1021 & - & $\nu$ & $\nu$ \\
\hline 1 & 160 & 15.1 & 35.2 & 7.66 & 1.84 & 1130 & 2330.55 & $\mathrm{X}$ & $\nu$ \\
\hline 2 & 160 & 17.3 & 35.4 & 7.63 & 1.89 & 1222 & 2383.26 & $\nu$ & $\nu$ \\
\hline 19 & 207 & 15.2 & 35.2 & 7.55 & 1.47 & 1466 & 2330.55 & $\nu$ & $\nu$ \\
\hline
\end{tabular}

environments (Figueira et al., 2012; Murray and Bowser, 2000) and it is inexpensive and relatively easy to use on a research cruise, where there may be limited facilities.

To view their preservation, some foraminifera were imaged using a JEOL JSM 6610 LV scanning electron microscope (SEM) with a digital imaging system. Individuals were mounted on aluminium SEM stubs and sputter coated in an Emitech K550 gold sputter coater.

The abundances of benthic foraminifera were used to calculate the Shannon-Wiener diversity index, the Fisher Alpha index and Pielou's evenness index. The Fisher Alpha index was used in addition to Shannon diversity as this is the most commonly used index in foraminiferal studies. Correlations between species richness, the number of individuals, Shannon-Wiener diversity index and environmental parameters were tested using Spearman's rank order correlation. As a means of testing whether there was a difference between stations with higher and lower $\mathrm{pH}$, a Mann-Whitney rank sum test was conducted on the data. The stations were separated into two groups: those with a low $\mathrm{pH}(7.55,7.63,7.66,7.69$ and $7.75(n=5))$ and those with a high $\mathrm{pH}(7.83,7.83,7.86$ and 7.88 $(n=4))$. SigmaPlot 12.0 was used to perform these analyses. Further statistical analysis was not undertaken due to limited sample numbers and sample size.

\section{Results}

\subsection{Environmental parameters}

The water chemistry data are based on single point measurements. Salinity ranged from $35.2 \%$ to $35.5 \%$ and total alkalinity ranged from 2331 to $2386 \mu \mathrm{mol} \mathrm{kg}{ }^{-1}$. The $\mathrm{pH}_{\mathrm{T}}$ of the bottom waters ranged from 7.55 to 7.88 , indicative of prevailing low $\mathrm{pH}$ conditions due to the presence of the $\mathrm{CO}_{2}$ vents. The seawater at all stations was oversaturated with respect to calcite ( $\left.\Omega_{\text {Calc }}\right)$, the lowest $\Omega_{\text {Calc }}$ value being 1.47 (Table 1 ). The aragonite saturation state $\left(\Omega_{\text {Arag }}\right.$ ) ranged from 0.95 to 2.37 , with undersaturation only at the station with the lowest $\mathrm{pH}$.

\subsection{Species composition}

\subsubsection{Living assemblages}

There were low numbers of living individuals present in all samples and three of the samples had no living individuals (Table 2). Two of the samples with no living individuals were stations with the highest $\mathrm{pH}$ (7.86 and 7.88 units). Of the living 


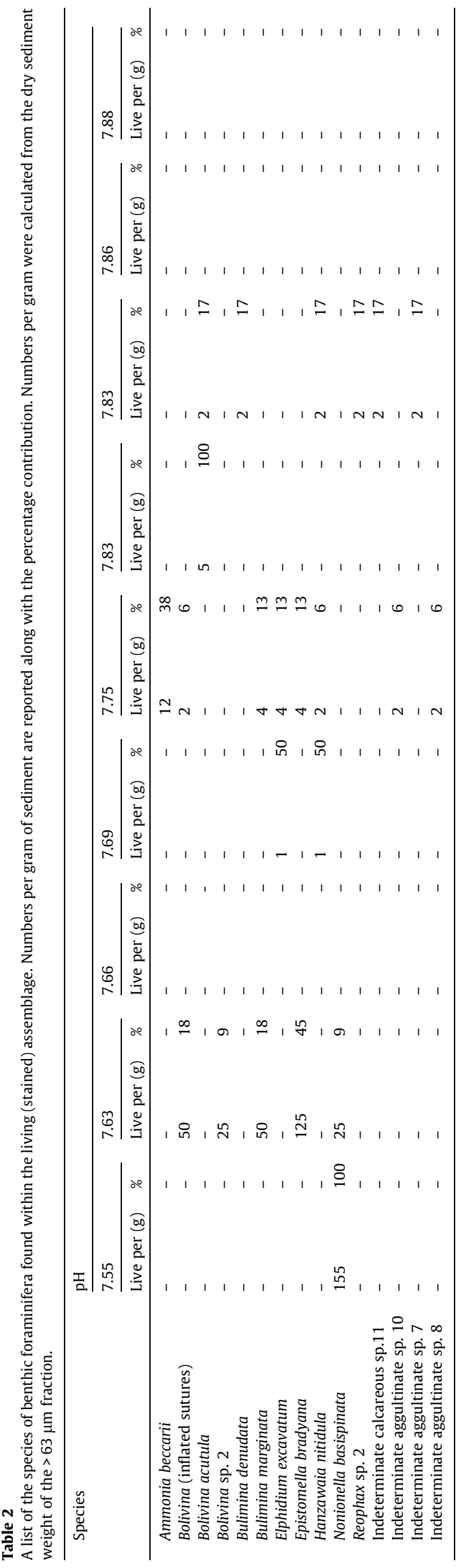

individuals found, the most abundant species were Nonionella basispinata (Cushman and Moyer) (37.7\%), Epistominella bradyana (Cushman) (27.0\%) and Bulimina marginata (d'Orbigny) (11.3\%). The numbers in brackets refer to the contribution of each species to the total number of living individuals.

Although some calcareous benthic foraminifera were present within the samples, the living assemblage was impoverished. The percentage of living individuals out of the total species assemblage (living and dead) varied from $0 \%$ to $20 \%$, with the highest percentage of living individuals occurring in the lowest $\mathrm{pH}$ sample. In addition to calcareous foraminifera, four species of agglutinated foraminifera with mineralised or proteinaceous cement were found within the living assemblage. These were found from two different sample stations. Dry picking may have resulted in the loss of some of the more fragile agglutinated taxa (Murray and Bowser, 2000), but these taxa were not the focus of this investigation. Dias et al. (2010) who also used the method of dry picking, found that the proportion of agglutinated taxa increased as $\mathrm{pH}$ decreased.

The highest species richness for any one sample was eight species. In those samples that did have living individuals, the Shannon-Wiener diversity index ranged from 0.00 to 1.84 , suggesting a low diversity in all samples. The number of individuals per gram appeared to increase with an increase in $\mathrm{pH}$, calcite saturation state and water temperature and decrease as water depth increased (Fig. 2). These apparent trends, however, were not statistically significant, although the low number of living specimens made it difficult to assess fully. Spearman's rank order correlation revealed that there was no significant correlation between species richness, the number of individuals per gram or the ShannonWeiner diversity index and $\mathrm{pH}_{\mathrm{T}}, \Omega_{\mathrm{Cal}}$, water depth or temperature $(p>0.050)$. The results of the Mann-Whitney rank sum test revealed that there was no significant difference in species richness ( $p=0.413)$ or the number of individuals per gram $(p=0.286)$ between the low and high $\mathrm{pH}$ groups.

\subsubsection{Dead assemblages}

Dead benthic foraminifera present in the top $2 \mathrm{~cm}$ of the sediment contained a selection of mainly calcareous taxa (including E. bradyana (54.5\%), B. marginata (13.5\%), Eponides sp. (7.4\%), Elphidium excavatum (Terquem) (6.4\%) and $N$. basispinata (3.8\%)) (Table 3 ). The numbers in brackets refer to the contribution of each species to the total number of dead individuals. These species are considered to constitute a normal composition for these water depths with the exception of E. excavatum which is typically a shallow water species occurring in water depths between 0 and $50 \mathrm{~m}$ (Murray, 1991). The presence of E. excavatum suggests possible down-slope transportation in the area.

Agglutinated taxa with mineralised or proteinaceous cement were found in seven of the samples and those with calcareous cement were found in only two samples. The only sample with no agglutinated foraminifera was the station with the lowest $\mathrm{pH}$. As mentioned above, dry picking may have resulted in the loss of some of the more fragile agglutinated taxa (Murray and Bowser, 2000).

The highest species richness for any one sample was 24 species and the lowest was nine species. Species richness appeared to increase with an increase in $\mathrm{pH}$, calcite saturation state and water temperature and decrease as water depth increased (Fig. 3). These patterns were statistically significant and Spearman's rank order correlation revealed that species richness increased as $\mathrm{pH}$ ( $r=0.79, p=0.009, n=9), \Omega_{\text {Calc }}(r=0.84, p=0.002, n=9)$ and water temperature $(r=0.88, p \leqslant 0.001, n=9)$ increased and decreased as water depth increased $(r=-0.96, p \leqslant 0.001, n=9)$. There was no significant correlation between the number of individuals per gram, the Shannon-Weiner diversity index or the Fisher Alpha index and $\mathrm{pH}_{\mathrm{T}}, \Omega_{\text {Calc }}$, water depth or temperature $(p>0.050)$. These 
results suggest that there was a reduction in species richness in the dead assemblage as $\mathrm{pH}$ decreased, but no statistically significant change in the number of individuals.

The results of the Mann-Whitney rank sum test revealed there to be a significant difference in species richness $(p=0.016)$ between the low and high pH groups. There was no statistically significant difference in the number of individuals per gram of sediment $(p=0.730)$, the Shannon-Wiener diversity index $(p=0.556)$, the Fisher Alpha index $(p=0.730)$, the number of calcareous species per gram $(p=0.730)$ or the number of agglutinated foraminifera per gram $(p=0.286)$ between the two groups (low and high $\mathrm{pH}$ ).

\subsection{Scanning electron microscopy}

A total of 40 different individuals (live and dead) were examined under the SEM, belonging to six species. The wall detail was examined under a higher magnification (up to x8000) in 26 of these individuals. The wall detail of the final chamber was examined if possible. Some individuals had their last chamber broken off, in which case the penultimate chamber was examined. Some dissolution was determined to have occurred if the foraminifera test showed etching, pitting, fragmentation or enlarged pores.

Unfortunately, the low number of living individuals limited the number that could be viewed under the SEM. Out of the 40 individuals examined under the SEM, 10 were living. Some of the living foraminifera $(30 \%)$ showed signs of dissolution, suggesting that they were able to live in the low $\mathrm{pH}$ conditions, but their tests were beginning to dissolve. Alternatively, the dissolution could be early post-mortem. Most of the dead individuals (60\%) showed signs of dissolution and many of these showed severe signs of dissolution, with extensive pitting and fragmentation.

Although there were signs of dissolution in some of the foraminifera, there were no deformities (such as abnormally shaped chambers) in any of the individuals examined under the SEM
(Fig. 4). This was also true in Ischia samples studied by Dias et al. (2010). Circular borings with a distinct profile were found in a few of the individuals examined (Fig. 5), which are thought to be caused by gastropods belonging to the families Naticidae and Muricidae (Maddocks, 1988). These are not, however, a dissolution feature and indicate that the specimen was almost certainly living when it was bored.

\section{Discussion}

Calcifying benthic foraminifera were present in $\mathrm{pH}$ conditions ranging from 7.55 to 7.88 near $\mathrm{CO}_{2}$ vents in the northern Gulf of California. Calcareous foraminifera dominated the species composition at the lowest pH stations. Our hypothesis that there would be a reduction in species richness and the number of calcifying species for the living assemblage in the lower $\mathrm{pH}$ conditions was not supported. Although the species richness and number of individuals was low, this was the case for all stations. The hypothesis that there would be evidence of test dissolution in calcareous benthic foraminifera was supported.

The range in $\mathrm{pH}$ between the stations was 0.33 units. Although this is less than the total decrease in $\mathrm{pH}(0.77$ units $)$ that is predicted to occur due to the anthropogenic burning of fossil fuels (Caldeira and Wickett, 2003), it still represents a large range in the concentration of hydrogen ions. The range in $\mathrm{pH}$ ( 0.33 units) is greater than the mean $\mathrm{pH}$ reductions ( $<0.05$ units) measured in bottom waters during an experiment assessing the impact of injected carbon dioxide on deep-sea benthic foraminifera (Bernhard et al., 2009a) and is similar to those expected along a dilution gradient, under carbon sequestration options (Bernhard et al., 2009a). The highest $\mathrm{pH}$ recorded was 7.88 , this below the value of 8.1 , which is considered to be a global average for surface waters (Guinotte and Fabry, 2008; Raven et al., 2005), but it is expected that infaunal benthic foraminifera will experience lower $\mathrm{pH}$ conditions within the sediment pore water. At the locations from which
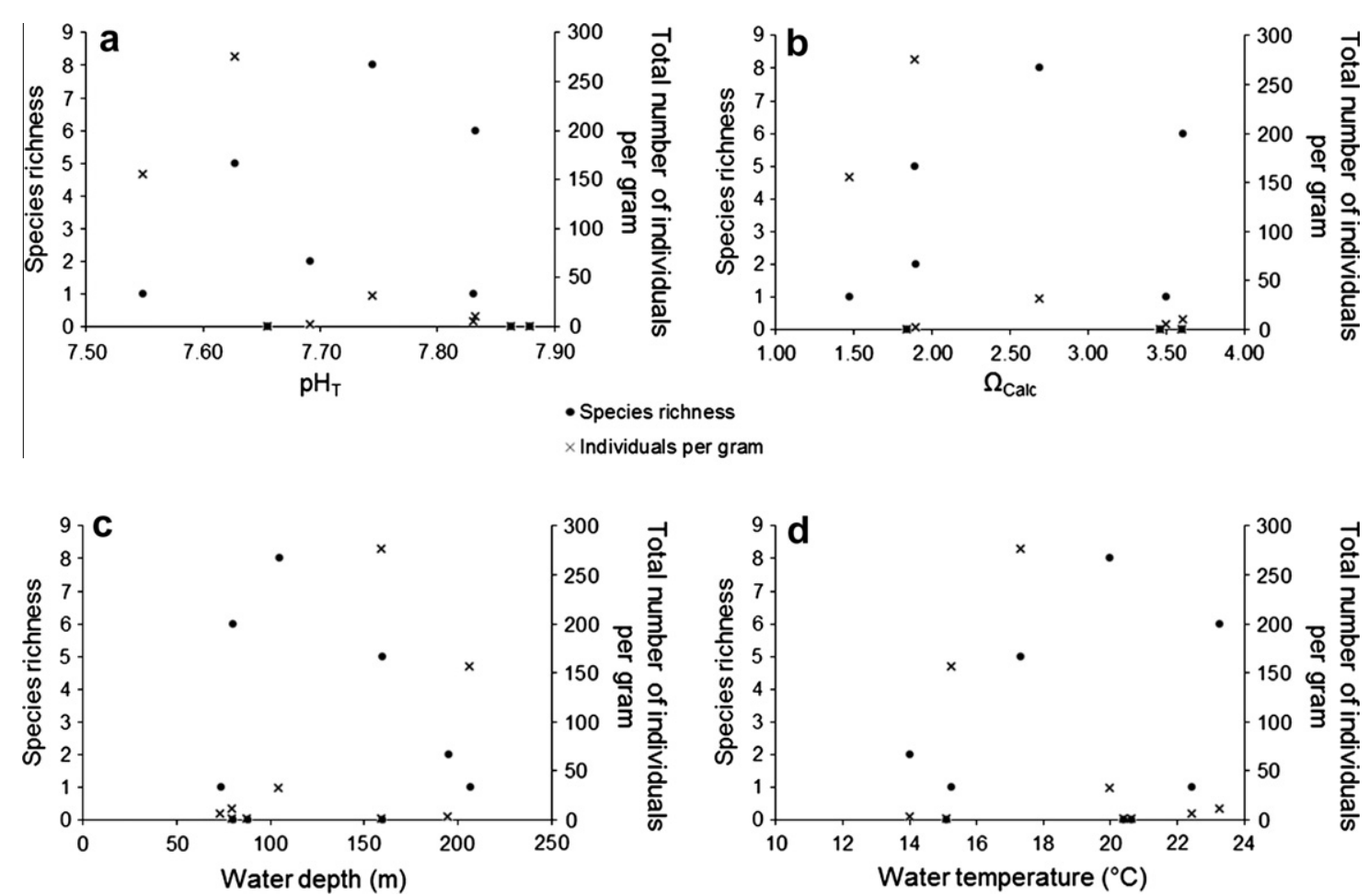

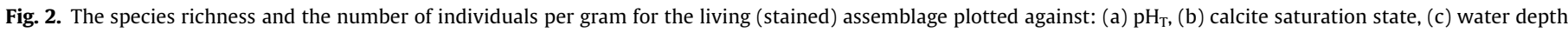
and (d) water temperature. 


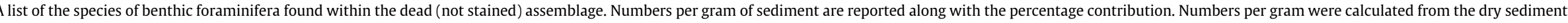
weight of the $>63 \mu \mathrm{m}$ fraction.

Species

\section{Ammonia beccarii}

Bolivina (inflated sutures)

Bolivina acuminata/spinosa

Bolivina acutula

Bolivina sp. 1

Bolivina sp. 2

Bolivina sp. 3

Bolivina sp. 4

Bolivina sp. 5

Buccella tenerrima

Bulimina denudata

Bulimina marginata

Bulimina sp. 1

Bulimina sp. 2

Cancris auricula

Cassidulina sp. 1

Cassidulina sp. 2

Elphidium excavatum

Epistomella bradyana

Eplidium sp. 1

Eponides sp. 1

Eponides sp. 2

Hanzawaia nitidula

Lagena sp. 1

Lagena sp. 2

Lenticulina

Loxostomum pseudoberyrichi

Nonionella basispinata

Nonionella sp. 1

Reophax sp. 1

Reophax sp. 2

Texturlaria sp. 1

Texturlaria sp. 2

Texturlaria sp. 3

Trochammina sp. 1

Trochammina sp. 2

Trochammina sp. 3

Trochammina sp. 4

Trochammina sp. 5

Uvigerina excellens

Veleroninoides sp.

Indeterminate calcareous sp. 1

Indeterminate calcareous sp. 2

Indeterminate calcareous sp. 3

Indeterminate calcareous sp. 4

Indeterminate calcareous sp. 6

Indeterminate calcareous sp. 7

Indeterminate calcareous sp. 8

Indeterminate calcareous sp. 9

Indeterminate calcareous sp. 10

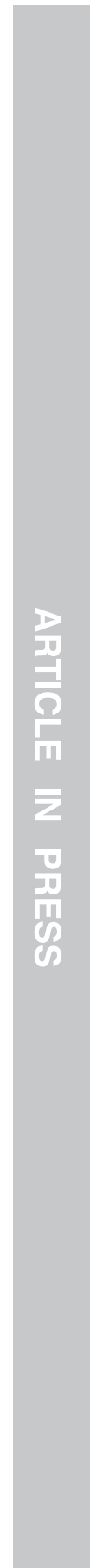




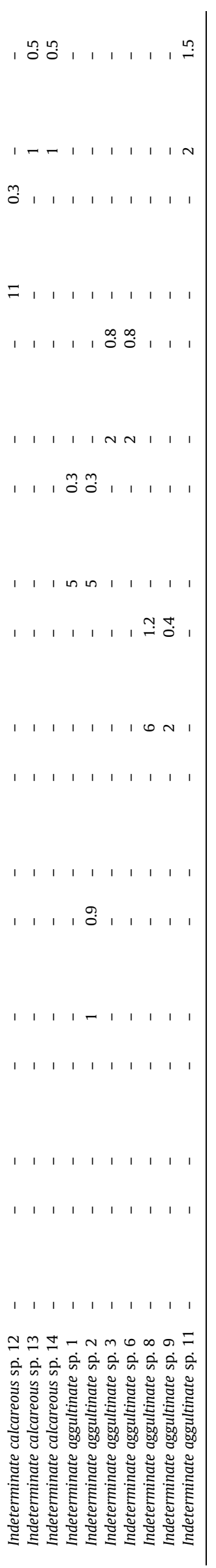

benthic foraminifera were examined, pore water $\mathrm{pH}$ ranged from 6.06 to 7.34 (Ruth Esther Villanueva-Estrada, unpublished data).

Some shallow water species Ammonia beccarii (Linné) and $E$. excavatum were found within the species assemblages. $A$. beccarii and $E$. excavatum typically live in water depths between 0 and $50 \mathrm{~m}$ (Murray, 1991). The presence these species suggests possible down-slope transportation in the area. Only a very small percentage of $A$. beccarii (3.3\%) and E. excavatum (0.6\%) were living. This suggests that the majority of the individuals had been washed into the sample sites and were not living in the vicinity of the vents. The one living $A$. beccarii examined under the SEM showed some signs of dissolution. Of the two living $E$. excavatum examined under the SEM, neither showed signs of dissolution.

Living calcareous species also included a mixture of infaunal and epifaunal taxa expected from these water depths such as $N$. basispinata (infaunal), B. marginata (infaunal) and E. bradyana (epifaunal) (Murray, 1991). It is perhaps surprising that more agglutinated foraminifera were not found within the species assemblage. Bandy (1961), who examined foraminifera from different depths and locations in the Gulf of California also reported low percentage contributions of agglutinated foraminifera. In the lowest $\mathrm{pH}$ conditions examined around $\mathrm{CO}_{2}$ vents at Ischia, Italy, Dias et al. (2010) found that agglutinated foraminifera dominated the assemblage, although there was a low species diversity.

There were no living Eponides species within the samples, whereas these dominated the dead assemblage. This suggests that these species were unable to survive in the low $\mathrm{pH}$ conditions or that they were not actually autochthonous and had been transported in from elsewhere. Eponides have been reported as dominating species assemblages in low oxygen environments $\left(0.25-1.1 \mathrm{ml} \mathrm{l}^{-1} \mathrm{O}_{2}\right)$ (Douglas and Heitman, 1979). Pore waters in anoxic sediments can sometimes be alkaline as a result of the sulphate-reducing bacteria (Murray, 1991), which involves the reduction of $\mathrm{CO}_{2}$ and the formation of hydrocarbons (Wright and Colling, 1995). This may explain why living Eponides species, which are typically tolerant of low oxygen, alkaline conditions, were not found in low $\mathrm{pH}$ conditions. Other taxa found within the living assemblage, however, such as Bolivina and Bulimina have also been found in low oxygen environments (Douglas and Heitman, 1979).

Dias et al. (2010) found a dramatic reduction in benthic foraminiferal diversity and abundance near to $\mathrm{CO}_{2}$ vents around Ischia Island, Italy. In contrast to our findings, no living calcareous foraminifera were found below $\mathrm{pH} \sim 7.6$ at Ischia (Dias et al., 2010) and Uthicke and Fabricius (2012) found no M. vertebralis at Papua New Guinea $\mathrm{CO}_{2}$ seep sites with pH below 7.9. Fabricius et al. (2011) found that high $p \mathrm{CO}_{2}$ had a negative impact on the number of calcareous benthic foraminifera at Papua New Guinea. Although we found some living calcareous benthic foraminifera, they were present in low numbers. Fabricius et al. (2011), however, did not distinguish between living and dead individuals. If the total assemblage (living and dead individuals) is considered from the northern Gulf of California samples, then disparity with Fabricius et al. (2011) seems to be even greater, as there was no reduction in the number of calcareous benthic foraminifera in the lowest $\mathrm{pH}$ sites.

Some living benthic foraminifera may be able to survive the low $\mathrm{pH}$ conditions in the northern Gulf of California due to the supply of nutrients and the availability of food. The northern Gulf of California is characterised by abundant nutrients which are carried to the surface through upwelling and tidal mixing (Halfar et al., 2004, 2006; Zeitzschel, 1969). A plentiful supply of food for foraminifera in the northern Gulf of California may enable them to persist in the stress of a low $\mathrm{pH}$ environment. Bolivina and Nonionella, two taxa found in this investigation, are typically found in organic rich environments (Kennett et al., 2000; Rathburn et al., 2000). In the high nutrient conditions of Kiel Fjord, calcifying invertebrates were found to dominate the macrobenthic 
community despite low pH conditions (Thomsen et al., 2010). Conversely, the Mediterranean Sea is an oligotrophic area in which nutrients decrease towards the east. Low pH conditions at Ischia will be an additional stress to that of limited food supply. Bacteria on the seagrass at Ischia, which would be expected to provide a food source for epiphytic foraminifera (Muller and Lee, 1969), are reported to have low densities (Novak, 1982; Velimirov, 1986; Velimirov et al., 1984). Limited food supply at Ischia could, therefore, be a reason for differences in the presence of living calcareous benthic foraminifera in the northern Gulf of California and Ischia.

Rodolfo-Metalpa et al. (2010) found that increased temperature and decreased $\mathrm{pH}$ acted synergistically to reduce calcification in the bryozoan Myriapora truncata at $\mathrm{CO}_{2}$ vents around Ischia. Further work revealed that the effects of ocean acidification on molluscs and corals were also exacerbated by high temperatures (Rodolfo-Metalpa et al., 2011). If the same principle applies to calcareous benthic foraminifera, this could be a possible explanation for their presence in the northern Gulf of California, but not Ischia or Papua New Guinea where seawater temperatures are higher. The shallow waters of Ischia and Papua New Guinea can warm quickly, resulting in temperatures up to $30^{\circ} \mathrm{C}$ at Ischia (Rodolfo-Metalpa et al., 2011). Temperature can control the major distribution patterns of shallow water foraminifera (Murray, 2006) and the higher seawater temperatures at Ischia may provide an additional stress to the benthic foraminifera. It may be the extent of the change in temperature, above or below the mean that is important, rather than the absolute temperature. The deeper environment and strong mixing in the northern Gulf of California means that temperature fluctuations are likely to be less severe than those in the shallow waters around Ischia and Papua New Guinea.

Variability in the calcite saturation state could also affect the ability of calcareous benthic foraminifera to survive in low $\mathrm{pH}$ conditions in the northern Gulf of California. The variability in $\Omega_{\text {Calc }}$ in the northern Gulf of California and at Papua New Guinea is unknown, but there is a high degree of variability at Ischia (Hall-Spencer et al., 2008; Kerrison et al., 2011). The emissions from the vents in the Wagner Basin are continuous and the $\mathrm{pH}$ recorded in this study roughly corresponds to $\mathrm{pH}$ values measured during the previous WAG-01 cruise. It is, therefore, expected that the saturation state will be fairly stable. In addition, the lack of strong temperature variations in the northern Gulf of California could mean that there is little variation in $\Omega_{\text {Calc }}$. It may be that foraminifera cannot survive in the variable saturation states at Ischia, and possibly Papua New Guinea, but more stable saturation states in the northern Gulf of California allow some to survive.

It is thought that in many organisms calcium carbonate saturation exerts the strongest control on calcification. As the saturation state reduces, the energetic cost of creating and maintaining biogenic calcium carbonate is expected to increase (de Nooijer et al., 2009a,b; Guinotte and Fabry, 2008; Orr et al., 2005; Riebesell et al., 2000). Differences in the saturation state were proposed as a possible explanation for differences in the abundance of the coccolithophore Emiliania huxleyi between the Baltic Sea and the Black Sea (Tyrrell et al., 2008). E. huxleyi were found to be abundant in the Black Sea, but absent from the Baltic Sea, which is surprising given their abundance in nearby waters at similar latitudes. Although differences in environmental factors, such as salinity or silicate concentration, could be an explanation for their absence, undersaturation with respect to aragonite and calcite in the Baltic Sea, but not the Black Sea, could also be an explanation. It is possible, however, that calcification rates in foraminifera are not related to calcite saturation state (de Villiers, 2004). Highest foraminifera shell weights were found not to have a straightforward relationship with saturation state; instead calcification appeared to be a function of the complex interplay of environmental parameters (de Villiers, 2004). This argues against the role that saturation state can play in determining the resilience of benthic foraminifera to ocean acidification.
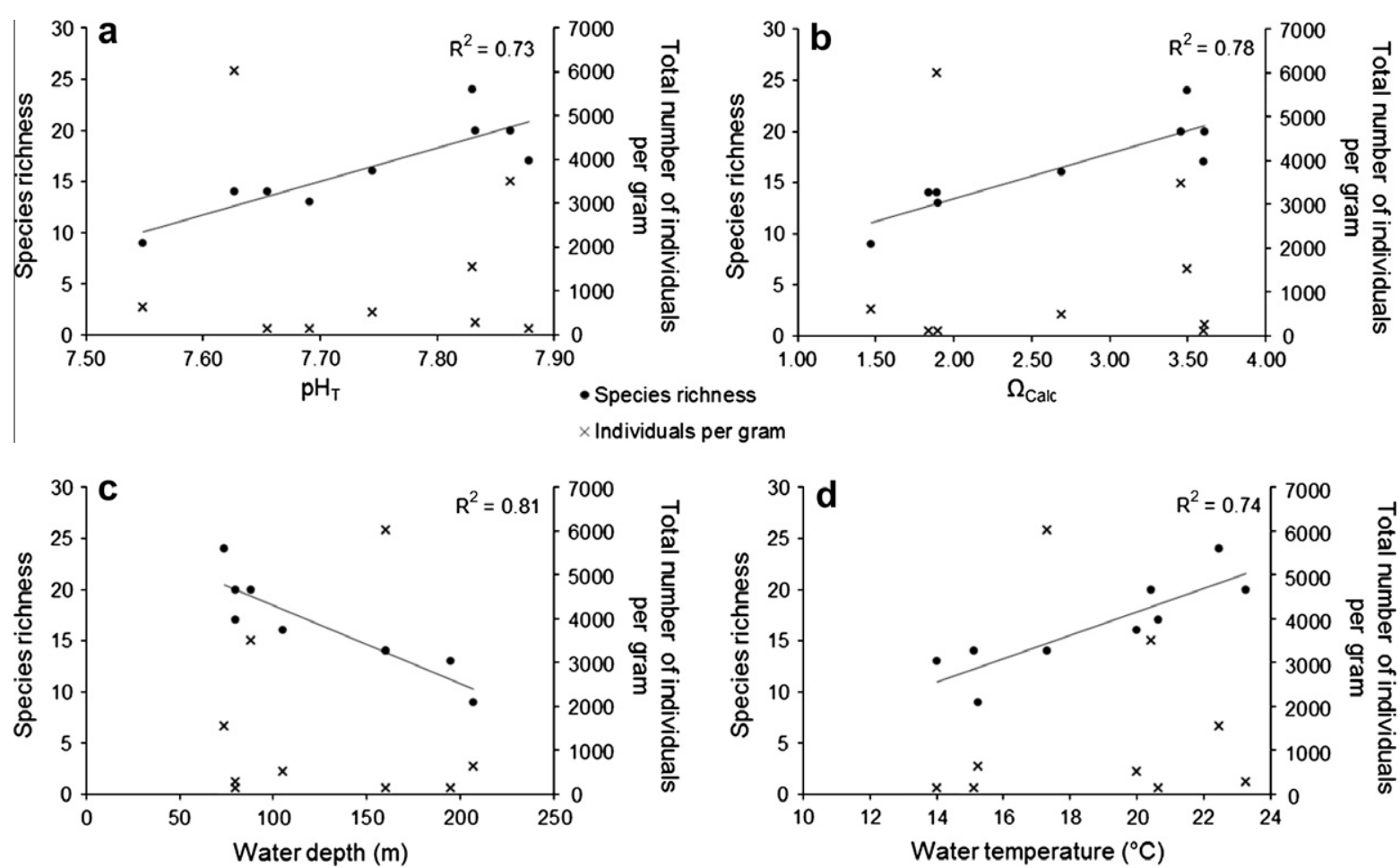

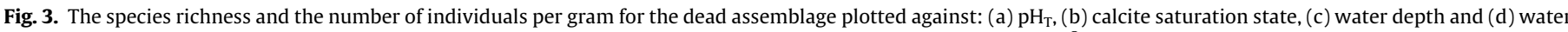
temperature. A linear trend line has been plotted on the graph for the species richness data points along with the $R^{2}$ value. 


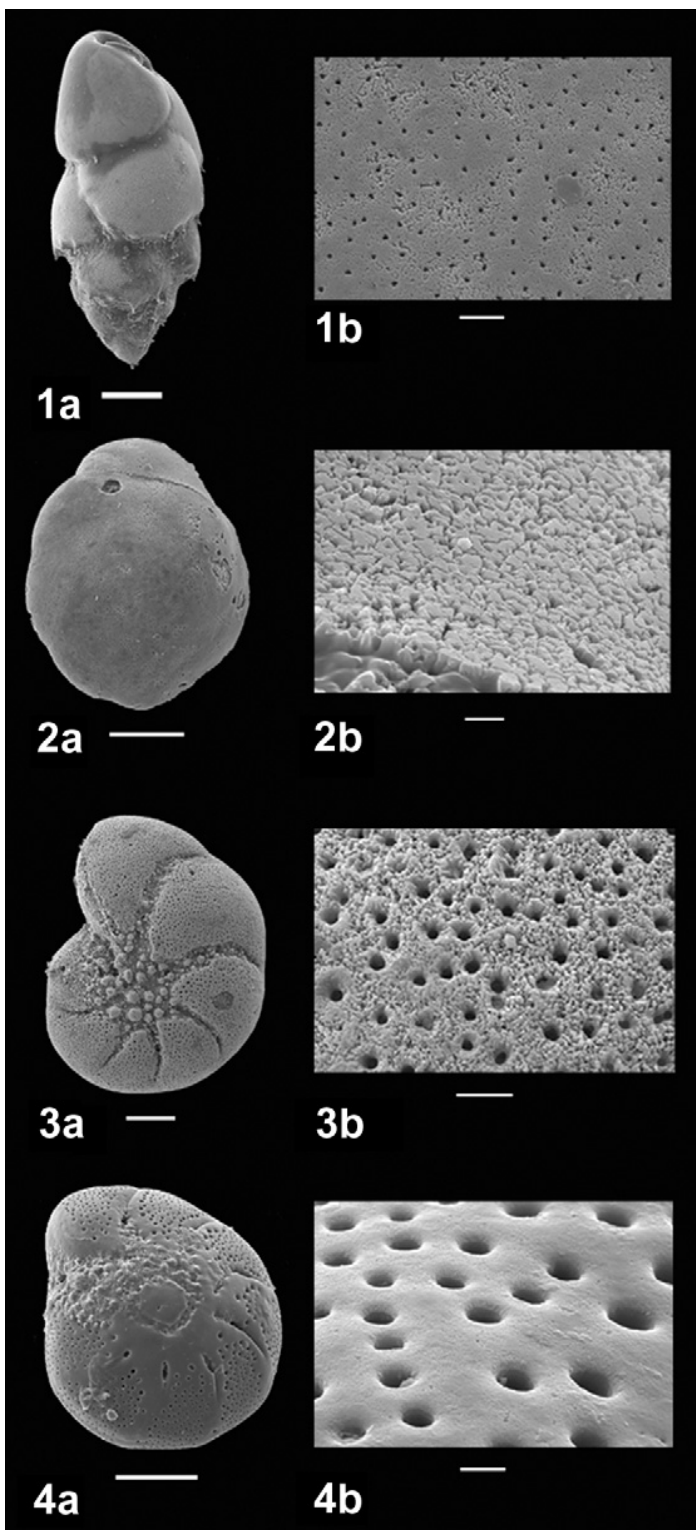

Fig. 4. Scanning electron microscope images of some living (stained) benthic foraminifera with wall details shown. (1a) Bulimina marginata from station 29 ( $\mathrm{pH}$ 7.75), (b) wall detail; (2a) Epistominella bradyana from station 29 ( $\mathrm{pH} 7.75$ ), (b) wall detail; (3a) Elphidium excavatum from station 29 ( $\mathrm{pH} 7.75$ ), (b) wall detail; (4a) E. excavatum from station 12 ( $\mathrm{pH} 7.69$ ), (b) wall detail. The scale bars for (1a, 2a, 3a and $4 \mathrm{a}$ ) are $50 \mu \mathrm{m}$, and the scale bars for ( $1 \mathrm{~b}, 2 \mathrm{~b}$ and $4 \mathrm{~b})$ are $2 \mu \mathrm{m}$; the scale bar for (3b) is $5 \mu \mathrm{m}$.

Foraminifera are thought to promote calcification by elevating their intracellular pH (de Nooijer et al., 2009a,b, 2008). A reduction in $\mathrm{pH}$ would, therefore, be expected to increase the amount of energy required to elevate intracellular $\mathrm{pH}$ to levels required for calcification. Alternatively, if the organisms are unable to elevate intracellular $\mathrm{pH}$ to the required levels, it is expected that there will be reduced carbonate concentrations for precipitation (de Nooijer et al., 2009b). Either of these two scenarios is likely to lead to a reduction in calcification. This view might be too simplistic and the methods used by de Nooijer et al. (2009b, 2008) are likely to lead to reduced resolution and unreliable $\mathrm{pH}$ measurements (Bentov et al., 2009). Bentov et al. (2009) observed that $\mathrm{Ca}^{2+}$ was supplied to the site of calcification in Amphistegina lobifera (Larsen), the benthic foraminifera, through the transport of seawater in vacuoles rather than through membrane ion transporters. The seawater vacuoles underwent alkalisation (to a $\mathrm{pH}$ of 8.7) during their intracellular passage which elevated $\mathrm{CO}_{3}^{2-}$ concentration. The energy expenditure of the foraminifera, needed to reach the required $\mathrm{pH}$ and maintain the same calcification rate, would still be determined by the initial saturation state of the seawater in the vacuole. The need for increased energy expenditure, in order to maintain the same rate of calcification, may explain why some of the living foraminifera examined under the SEM showed signs of dissolution. Although the foraminifera were still living in the low $\mathrm{pH}$ sites, they may not have had the required energy to maintain their calcification rate.

It is also possible that the calcareous benthic foraminifera experience increased dissolution of their tests. Rodolfo-Metalpa et al. (2011) found that when corals and molluscs were transplanted near to $\mathrm{CO}_{2}$ vents in the Mediterranean, they were still able to calcify and grow faster, but dissolution rates of their calcium carbonate skeletons increased. This may also be the case for benthic foraminifera in the northern Gulf of California. It may be that in some low $\mathrm{pH}$ environments, although the foraminifera are still able to produce their calcium carbonate tests, they have thinner or smaller tests and reduced shell weights. This was found in a study of planktic foraminifera in the Southern Ocean (Moy et al., 2009). When comparing sediment trap data with sediments of preindustrial age, Moy et al. (2009) found approximately a 30-35\% reduction in the shell weight of Globigerina bulloides (d'Orbigny).

Our results indicate that some benthic foraminifera might be able to survive in low $\mathrm{pH}$ conditions due to carbon dioxide injection at a CCS site. It is likely, however, that the species assemblage will be reduced and the living foraminifera may experience test dissolution. This is similar to the findings of Bernhard et al. (2009a) who found that calcareous foraminifera had significantly lower survivorship under a potential carbon dioxide sequestration scenario. The examination of foraminifera from an area naturally lower in $\mathrm{pH}$ means that any foraminifera living in the area are likely to have experienced the low $\mathrm{pH}$ conditions throughout their life span.

Foraminifera must have survived in high $\mathrm{CO}_{2}$ environments that occurred during the Cretaceous-Paleogene "greenhouse" world

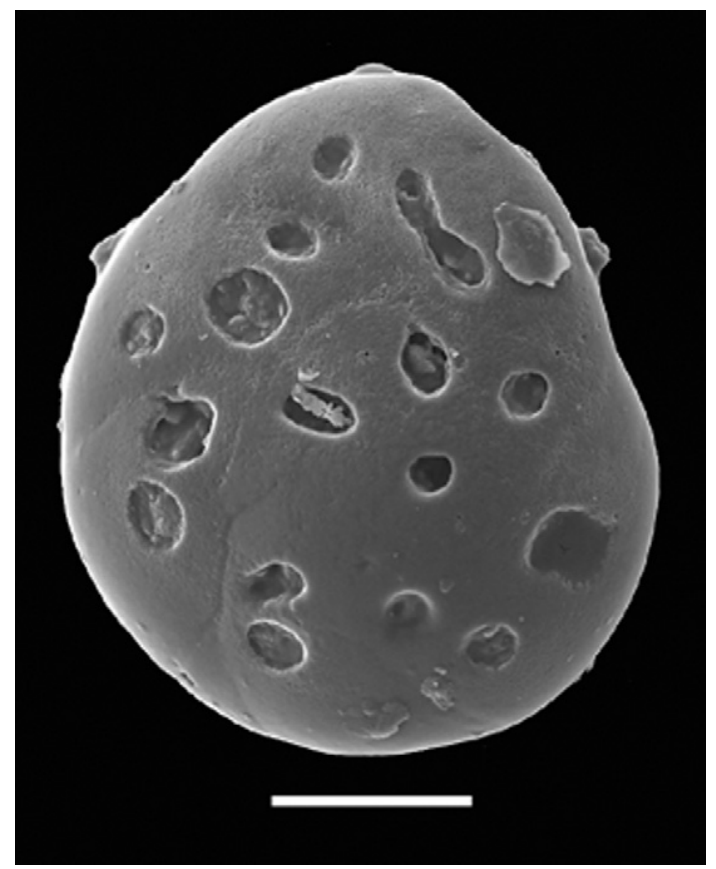

Fig. 5. An SEM image of Epistominella bradyana from station $9(\mathrm{pH} 7.83$ ) with evidence of boring features. The roundness and evenness of the features suggest a biological origin, thought to be caused by gastropods belonging to the families Naticidae and Muricidae. This specimen was not living. The scale bar is $50 \mu \mathrm{m}$. 
where atmospheric $p \mathrm{CO}_{2}$ was very much higher (estimates have ranged from $\sim 1000 \mathrm{ppm}$ up to $\sim 4000 \mathrm{ppm}$ ), but with calcareous foraminifera apparently thriving (Andrews et al., 1995; Berner, 1990; Berner et al., 1983; Bice and Norris, 2002; Caldeira and Rampino, 1991; Kintisch, 2006; Royer et al., 2004; Tyrrell and Zeebe, 2004; Walker et al., 1981). Concentrations of $\mathrm{CO}_{3}{ }^{2-}$ are thought to have almost quadrupled since the Cretaceous and $\mathrm{pH}$ has increased, whilst the calcium carbonate saturation state has varied very little (Tyrrell and Zeebe, 2004). This suggests that foraminifera were able to survive in the low $\mathrm{pH}$ conditions $(\sim 0.6$ to $0.7 \mathrm{pH}$ units lower than present day) of the Cretaceous because the calcite saturation state remained high (Stanley and Hardie, 1998). It is possible that the saturation state was decoupled from pH and remained high (Hönisch et al., 2012; Ridgwell and Schmidt, 2010). In events involving a geologically rapid release of $\mathrm{CO}_{2}$, such as is occurring in the present day, the balances between sources (weathering) and sinks $\left(\mathrm{CaCO}_{3}\right.$ burial) of calcium will not be able to respond fast enough to regulate $\Omega$. This will result in a coupled decline of both $\mathrm{pH}$ and $\Omega$ (Ridgwell and Schmidt, 2010).

\section{Conclusions}

Examination of calcareous benthic foraminifera collected from around natural $\mathrm{CO}_{2}$ vents in the northern Gulf of California has revealed that they show some resilience to low $\mathrm{pH}$ conditions. Living calcareous benthic foraminifera were present in $\mathrm{pH}$ conditions as low as 7.55 units, albeit in low numbers. Although these results have some similarities to the findings from other shallow water $\mathrm{CO}_{2}$ vents at Papua New Guinea (Fabricius et al., 2011) and Ischia (Dias et al., 2010), calcareous species were not found in the lowest $\mathrm{pH}$ conditions ( $\sim 7.6$ units) examined at Ischia. Differences in nutrient concentrations and saturation state variability in the northern Gulf of California may be a possible explanation for the discrepancies. There was some evidence of dissolution in individuals examined under the SEM at relatively high magnification. This could be a result of the foraminifera not being able to meet the increased energy requirements to maintain the same calcification rate under low $\mathrm{pH}$ conditions, or a result of increased dissolution of their tests.

\section{Acknowledgements}

The authors would like to thank K. MacPherson for her help with the sampling processing and G. Harper, P. Bond and R. Moate for their help with the SEM. We would also like to thank the editors and three anonymous referees for helpful suggestions that have helped improve the paper. Financial support was provided by FONCICYT 94482-Recursos Geotérmicos submarinos del Norte del Golfo de California. This research was supported jointly by the European Union and Mexico. LP is carrying out a PhD funded by the NERC UKOARP. This article contributes to the EU FP7 project on 'Mediterranean Sea Acidification under a changing climate' (MedSeA Grant agreement no. 265103) with additional funding for JHS from the Save Our Seas Foundation.

\section{References}

Andrews, J., Tandon, S., Dennis, P., 1995. Concentration of carbon dioxide in the Late Cretaceous atmosphere. Journal of the Geological Society, London 152, 1-3.

Bandy, O.L., 1953. Ecology and paleoecology of some California foraminifera. Part I. The frequency distribution of recent foraminifera off California. Journal of Paleontology 27, 161-182.

Bandy, O.L., 1961. Distribution of foraminifera, radiolaria and diatoms in sediments of the Gulf of California. Micropaleontology 7, 1-26.

Barker, S., Elderfield, H., 2002. Foraminiferal calcification response to glacialinterglacial changes in atmospheric $\mathrm{CO}_{2}$. Science 297, 833-836.

Bentov, S., Brownlee, C., Erez, J., 2009. The role of seawater endocytosis in the biomineralization process in calcareous foraminifera. Proceedings of the National Academy of Sciences 106, 21500-21504.
Berner, R.A., 1990. Atmospheric carbon dioxide levels over Phanerozoic time Science 249, 1382-1386.

Berner, R.A., Lasaga, A.C., Garrels, R.M., 1983. The carbonate-silicate geochemical cycle and its effect on atmospheric carbon dioxide over the past 100 million years. American Journal of Science 283, 641-683.

Bernhard, J.M., 2000. Distinguishing live from dead foraminifera: methods review and proper applications. Micropaleontology 46, 38-46.

Bernhard, J.M., Ostermann, D.R., Williams, D.S., Blanks, J.K., 2006. Comparison of two methods to identify live benthic foraminifera: a test between Rose Bengal and Cell Tracker Green with implications for stable isotope paleoreconstructions. Paleoceanography 21, PA4210.

Bernhard, J., Barry, J., Buck, K., Starczak, V., 2009a. Impact of intentionally injected carbon dioxide hydrate on deep sea benthic foraminiferal survival. Global Change Biology 15, 2078-2088.

Bernhard, J.M., Mollo-Christensen, E., Eisenkolb, N., Starczak, V.R., 2009b. Tolerance of allogromiid Foraminifera to severely elevated carbon dioxide concentrations: implications to future ecosystem functioning and paleoceanographic interpretations. Global and Planetary Change 65, 107-114.

Bice, K.L., Norris, R.D., 2002. Possible atmospheric $\mathrm{CO}_{2}$ extremes of the middle Cretaceous (late Albian-Turonian). Paleoceanography 17, 1070-1087.

Bijma, J., Spero, H., Lea, D., 1999. Reassessing foraminiferal stable isotope geochemistry: Impact of the oceanic carbonate system (experimental results). In: Fischer, G., Wefer, G. (Eds.), Use of Proxies in Paleoceanography: Examples from the South Atlantic. Springer-Verlag, Berlin, pp. 489-512.

Bijma, J., Honisch, B., Zeebe, R., 2002. Impact of the ocean carbonate chemistry on living foraminiferal shell weight: comment on "Carbonate ion concentration in glacial-age deepwaters of the Caribbean Sea" by W.S. Broecker and E. Clark. Geochemistry, Geophysics, Geosystems 3, 1064.

Blackford, J., Jones, N., Proctor, R., Holt, J., Widdicombe, S., Lowe, D., Rees, A., 2009. An initial assessment of the potential environmental impact of $\mathrm{CO}_{2}$ escape from marine carbon capture and storage systems. In: Proceedings of the Institution of Mechanical Engineers, Part A: Journal of Power and Energy, vol. 223. pp. 269280.

Brenner, G.J., 1962. Results of the Puritan-American museum of natural history expedition to Western Mexico. 14, A zoogeographic analysis of some shallowwater Foraminifera in the Gulf of California. Bulletin of the American Museum of Natural History 123, 253-297.

Caldeira, K., Rampino, M.R., 1991. The mid-cretaceous super plume, carbon dioxide and global warming. Geophysical Research Letters 18, 987-990.

Caldeira, K., Wickett, M., 2003. Anthropogenic carbon and ocean pH. Nature 425, 365.

Canet, C., Prol-Ledesma, R.M., Dando, P.R., Vázquez-Figueroa, V., Shumilin, E., Birosta, E., Sánchez, A., Robinson, C.J., Camprubí, A., Tauler, E., 2010. Discovery of massive seafloor gas seepage along the Wagner Fault, northern Gulf of California. Sedimentary Geology 228, 292-303.

Corliss, B.H., 1985. Microhabitats of benthic foraminifera within deep-sea sediments. Nature $314,435-438$.

de Nooijer, L., Toyofuku, T., Oguri, K., Nomaki, H., Kitazato, H., 2008. Intracellular pH distribution in foraminifera determined by the fluorescent probe HPTS Limnology and Oceanography: Methods 6, 610-618.

de Nooijer, L., Langer, G., Nehrke, G., Bijma, J., 2009a. Physiological controls on seawater uptake and calcification in the benthic foraminifer Ammonia tepida. Biogeosciences 6, 2669-2675.

de Nooijer, L.J., Toyofuku, T., Kitazato, H., 2009b. Foraminifera promote calcification by elevating their intracellular $\mathrm{pH}$. Proceedings of the National Academy of Sciences 106, 15374-15378.

de Villiers, S., 2004. Optimum growth conditions as opposed to calcite saturation as a control on the calcification rate and shell-weight of marine foraminifera. Marine Biology 144, 45-49.

Dias, B.B., Hart, M.B., Smart, C.W., Hall-Spencer, J.M., 2010. Modern seawate acidification: the response of foraminifera to high- $\mathrm{CO}_{2}$ conditions in the Mediterranean Sea. Journal of the Geological Society, London 167, 843846.

Dickson, A.G., Sabine, C.L., Christian, J.R., 2007. Guide to best practices for ocean $\mathrm{CO}_{2}$ measurements. PICES special publication 3. IPCC Report number 8, 175pp.

Douglas, R.G., Heitman, H.L., 1979. Slope and basin benthic foraminifera of the California borderland. The Society of Economic Paleontologists and Mineralogists (SEPM) Special Publication, vol. 27, pp. 231-246.

Fabricius, K.E., Langdon, C., Uthicke, S., Humphrey, C., Noonan, S., De'ath, G. Okazaki, R., Muehllehner, N., Glas, M.S., Lough, J.M., 2011. Losers and winners in coral reefs acclimatized to elevated carbon dioxide concentrations. Nature Climate Change 1, 165-169.

Figueira, B.O., Grenfell, H.R., Hayward, B.W., Alfaro, A.C., 2012. Comparison of rose Bengal and Celltracker Green staining for identification of live salt-marsh foraminifera. Journal of Foraminiferal Research 42, 206-215.

Gonzalez-Mora, B., Sierro, F., Flores, J., 2008. Controls of shell calcification in planktonic foraminifers. Quaternary Science Reviews 27, 956-961.

Guinotte, J.M., Fabry, V.J., 2008. Ocean acidification and its potential effects on marine ecosystems. Annals of the New York Academy of Sciences 1134, 320 342.

Halfar, J., Godinez-Orta, L., Mutti, M., Valdez-Holguín, J.E., Borges, J.M., 2004 Nutrient and temperature controls on modern carbonate production: an example from the Gulf of California, Mexico. Geology 32, 213-216.

Halfar, J., Godinez-Orta, L., Mutti, M., Valdez-Holguin, J., Borges, J., 2006. Carbonates calibrated against oceanographic parameters along a latitudinal transect in the Gulf of California, Mexico. Sedimentology 53, 297-320. 
Hall-Spencer, J.M., Rodolfo-Metalpa, R., Martin, S., Ransome, E., Fine, M., Turner S.M., Rowley, S.J., Tedesco, D., Buia, M.-C., 2008. Volcanic carbon dioxide vents show ecosystem effects of ocean acidification. Nature 454, 96-99.

Hönisch, B., Ridgwell, A., Schmidt, D.N., Thomas, E., Gibbs, S.J., Sluijs, A., Zeebe, R., Kump, L., Martindale, R.C., Greene, S.E., 2012. The Geological Record of Ocean Acidification. Science 335, 1058-1063.

Kennett, J.P., Cannariato, K.G., Hendy, I.L., Behl, R.J., 2000. Carbon isotopic evidence for methane hydrate instability during Quaternary interstadials. Science 288 , $128-133$.

Kerrison, P., Hall-Spencer, J.M., Suggett, D., Hepburn, L.J., Steinke, M., 2011. Assessment of $\mathrm{pH}$ variability at a coastal $\mathrm{CO}_{2}$ vent for ocean acidification studies. Estuarine, Coastal and Shelf Science 94, 129-137.

Kintisch, E., 2006. Hot times for the Cretaceous Oceans. Science 311, 1095.

Kroeker, K.J., Kordas, R.L., Crim, R.N., Singh, G.G., 2010. Meta-analysis reveals negative yet variable effects of ocean acidification on marine organisms. Ecology Letters 13, 1419-1434.

Le Cadre, V., Debenay, J.P., Lesourd, M., 2003. Low pH effects on Ammonia beccarii test deformation: implications for using test deformations as a pollution indicator. Journal of Foraminiferal Research 33, 1-9.

Lesen, A.E., 2005. Relationship between benthic foraminifera and food resources in South San Francisco Bay, California, USA. Marine Ecology Progress Series 297 131-145.

Lewis, E., Wallace, D.W.R., 1998. Program developed for $\mathrm{CO}_{2}$ system calculations. ORNL/CDIAC-105. Carbon Dioxide Information Analysis Center, Oak Ridge National Laboratory, US Dept. of Energy, Oak Ridge. Tennessee.

Loeblich, A.R. Jr., Tappan, H., 1964. Sarcodina. Chiefly "Thecamoebians and Foraminifera. Treatise on invertebrate paleontology. Part C. The Geological Society of America and the University of Kansas Press, 900 pp.

Loeblich, A.R. Jr., Tappan, H., 1987. Foraminiferal genera and their classification. Van Nostrand Reinhold New York, 1728pp.

Maddocks, R.F., 1988. One hundred million years of predation on ostracods: the fossil record in Texas. Developments in Palaeontology and Stratigraphy 11, 637-657.

McGann, M., 2002. Historical and modern distributions of benthic foraminifers on the continental shelf of Monterey Bay, California. Marine Geology 181, 115156.

Mehrbach, C., Culberson, C., Hawley, J., Pytkowicz, R., 1973. Measurement of the apparent dissociation constants of carbonic acid in seawater at atmospheric pressure. Limnology and Oceanography 18, 897-907.

Moy, A.D., Howard, W.R., Bray, S.G., Trull, T.W., 2009. Reduced calcification in modern Southern Ocean planktonic foraminifera. Nature Geoscience 2, 276280.

Muller, W.A., Lee, J.J., 1969. Apparent indispensability of Bacteria in foraminiferan nutrition. Journal of Eukaryotic Microbiology 16, 417-478.

Murray, J.W., 1991. Ecology and Palaeoecology of Benthic Foraminifera. Longman Scientific \& Technical, Harlow, 408 pp.

Murray, J.W., 2006. Ecology and Applications of Benthic Foraminifera. Cambridge University Press, Cambridge, 426 pp.

Murray, J.W., Bowser, S.S., 2000. Mortality, protoplasm decay rate, and reliability of staining techniques to recognize 'living' foraminifera: a review. Journal of Foraminiferal Research 30, 66.

Nguyen, T.M.P., Petrizzo, M.R., Speijer, R.P., 2009. Experimental dissolution of a fossil foraminiferal assemblage (Paleocene-Eocene Thermal Maximum, Dababiya, Egypt): implications for paleoenvironmental reconstructions. Marine Micropaleontology 73, 241-258.

Novak, R., 1982. Spatial and seasonal distribution of the meiofauna in the seagrass Posidonia oceanica. Netherlands Journal of Sea Research 16, 380-388.

Orr, J.C., Fabry, V.J., Aumont, O., Bopp, L., Doney, S.C., Feely, R.A., Gnanadesikan, A., Gruber, N., Ishida, A., Joos, F., Key, R.M., Lindsay, K., Maier-Reimer, E., Matear, R., Monfray, P., Mouchet, A., Najjar, R.G., Plattner, G.-K., Rodgers, K.B., Sabine, C.L., Sarmiento, J.L., Schlitzer, R., Slater, R.D., Totterdell, I.J., Weirig, M.-F., Yamanaka, Y., Yool, A., 2005. Anthropogenic ocean acidification over the twenty-first century and its impact on calcifying organisms. Nature 437, 681-686.
Pielou, E., 1966. The measurement of diversity in different types of biological collections. Journal of Theoretical Biology 13, 131-144.

Prol-Ledesma, R.M., Torres-Vera, M.A., Rodolfo-Metalpa, R., Ángeles, C., Lechuga Deveze, C.H., Villanueva-Estrada, R.E., Shumilin, E., Robinson, C., 2013. High heat flow and ocean acidification at a nascent rift in the northern Gulf of California. Nature Communications 4, 1388. http://dx.doi.org/10.1038/ncomms.2390.

Rathburn, A.E., Levin, L.A., Held, Z., Lohmann, K.C., 2000. Benthic foraminifera associated with cold methane seeps on the northern California margin: ecology and stable isotopic composition. Marine Micropaleontology 38, 247-266.

Raven, J., Caldeira, K., Elderfield, H., Hoegh-Guldberg, O., Liss, P., Riebesell, U., Shepherd, J., Turley, C., Watson, A., 2005. Ocean Acidification due to Increasing Atmospheric Carbon Dioxide. The Royal Society, London, $60 \mathrm{pp}$

Ridgwell, A., Schmidt, D.N., 2010. Past constraints on the vulnerability of marine calcifiers to massive carbon dioxide release. Nature Geoscience 3, 196-200.

Riebesell, U., Zondervan, I., Rost, B., Tortell, P.D., Zeebe, R.E., Morel, F.M.M., 2000. Reduced calcification of marine plankton in response to increased atmospheric $\mathrm{CO}_{2}$. Nature 407, 364-367.

Rodolfo-Metalpa, R., Lombardi, C., Cocito, S., Hall-Spencer, J.M., Gambi, M.C., 2010. Effects of ocean acidification and high temperatures on the bryozoan Myriapora truncata at natural $\mathrm{CO}_{2}$ vents. Marine Ecology 31, 447-456.

Rodolfo-Metalpa, R., Houlbrèque, F., Tambutté, É., Boisson, F., Baggini, C., Patti, F., Jeffree, R., Fine, M., Foggo, A., Gattuso, J., 2011. Coral and mollusc resistance to ocean acidification adversely affected by warming. Nature Climate Change 1 , 308-312.

Royer, D.L., Berner, R.A., Montañez, I.P., Tabor, N.J., Beerling, D.J., 2004. $\mathrm{CO}_{2}$ as a primary driver of Phanerozoic climate. GSA Today 14, 4-10.

Sabine, C.L., Feely, R.A., Gruber, N., Key, R.M., Lee, K., Bullister, J.L., Wanninkhof, R., Wong, C.S., Wallace, D.W.R., Tilbrook, B., Millero, F.J., Peng, T.-H., Kozyr, A., Ono, T., Rios, A.F., 2004. The oceanic sink for anthropogenic $\mathrm{CO}_{2}$. Science 305, 367371.

Spero, H., Bijma, J., Lea, D., Bemis, B., 1997. Effect of seawater carbonate concentration on foraminiferal carbon and oxygen isotopes. Nature 390, 497500.

Stanley, S.M., Hardie, L.A., 1998. Secular oscillations in the carbonate mineralogy of reef-building and sediment-producing organisms driven by tectonically forced shifts in seawater chemistry. Palaeogeography, Palaeoclimatology, Palaeoecology 144, 3-19.

Thomsen, J., Gutowska, M., Saphörster, J., Heinemann, A., Trübenbach, K., Fietzke, J., Hiebenthal, C., Eisenhauer, A., Körtzinger, A., Wahl, M., 2010. Calcifying invertebrates succeed in a naturally $\mathrm{CO}_{2}$ enriched coastal habitat but are threatened by high levels of future acidification. Biogeosciences 7, 3879-3891.

Tyrrell, T., Zeebe, R.E., 2004. History of carbonate ion concentration over the last 100 million years. Geochimica et Cosmochimica Acta 68, 3521-3530.

Tyrrell, T., Schneider, B., Charalampopoulou, A., Riebesell, U., 2008. Coccolithophores and calcite saturation state in the Baltic and Black Seas. Biogeosciences 5, 485-494.

Uthicke, S., Fabricius, K., 2012. Productivity gains do not compensate for reduced calcification under near-future ocean acidification in the photosynthetic benthic foraminifer species Marginopora vertebralis. Global Change Biology 18, 2781-2791

Velimirov, B., 1986. DOC dynamics in a Mediterranean seagrass system. Marine Ecology Progress Series 28, 21-41.

Velimirov, B., Herndl, G., Kavka, G., 1984. Biomass distribution and physiological capabilities of bacteria in the water column above a sea grass system, Deuxiéme Colloque International de Bactériologie Marine, CRNS, Brest (France). 1-5 octobre 1984. IFREMER, Actes de Colloques, vol. 3, pp. 129-136.

Walker, J.C.G., Hays, P., Kasting, J., 1981. A negative feedback mechanism for the long-term stabilization of the Earth's surface temperature. Journal of Geophysical Research 86, 9776-9782.

Wright, J., Colling, A., 1995. Seawater: Its Composition, Properties, and Behaviour, second ed. Pergamon Press, Oxford, 166 pp.

Zeitzschel, B., 1969. Primary productivity in the Gulf of California. Marine Biology 3, 201-207. 